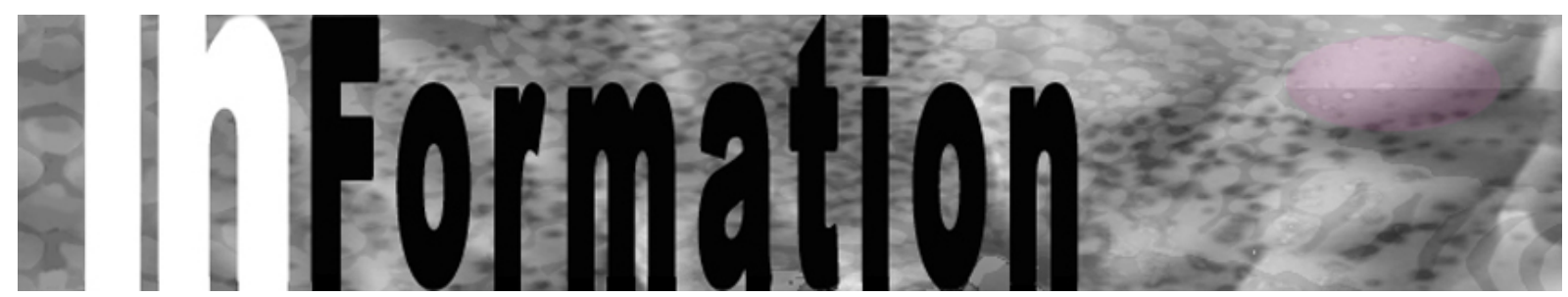

Nordic Journal of Art and Research

ISSN: $1893-2479$

www.artandresearch.info

\title{
"I think the arts are as prominent as any subject": A study of arts education in two Scandinavian schools
}

\author{
Catharina Christophersen ${ }^{1} \&$ Cecilia Ferm Thorgersen ${ }^{2}$
}

\author{
Bergen University College, Luleå University of Technology
}

\begin{abstract}
The arts seem to be under pressure in many educational systems, which is demonstrated by a general lack of recognition of aesthetic experience and learning, a lack of emphasis on the arts in education, and often also a lack of fully competent teachers. Despite the challenging situation facing the arts in schools in general, there are exceptions. Some schools do choose to focus on the arts. This article is based on an ethnographic double case study that explored arts education practices in two such Scandinavian schools. The purpose was to examine how education in the arts subjects was carried out in the schools, and how the actors perceived, articulated and legitimated the educational practices in the arts subjects. The case descriptions of the two schools imply that the educational leadership in the schools were of great importance. Further, that the arts are integrated as a natural part of everyday school life, and both schools have taken a holistic approach to education, in which the arts are perceived to involve and contribute to learning in the broadest sense, as well as to the pupils' social and personal growth. Also, the case descriptions show that arts education practices were carried out in a creative, but challenging tension between frames and freedom.
\end{abstract}

Keywords: Arts education, arts in schools, music, arts and crafts, arts education philosophy, arts education leadership, case study.

\section{Introduction}

Western education is currently characterized by strong focus on goal attainment and basic skills. School systems world-wide seem to "focus far more on training what are considered 'academic skills' (...) and far less on the arts" (Winner et al, 2013, p. 29). The arts seem to be under pressure in many educational systems. This is demonstrated by a general lack of recognition of aesthetic experience and

\footnotetext{
${ }^{1}$ Bergen University College, Faculty of Education, Box 7030, 5020 Bergen, Norway. E-mail: catharina.christophersen@,hib.no.

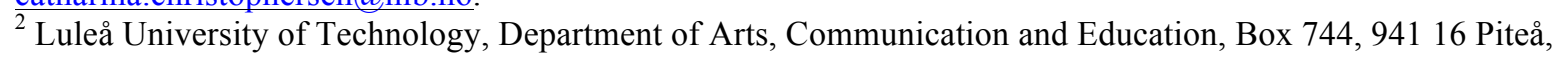
Sweden. E-mail: cecilia.ferm@1tu.se.
} 
learning, a lack of emphasis on the arts in education, and often also a lack of fully competent teachers (Bamford, 2006). Despite the challenging situation facing the arts in schools in general, there are exceptions. Some schools choose to focus on the arts. It is crucial to describe and discuss educational practices that take the arts seriously. Such practices can illustrate the opportunities and challenges the arts and aesthetic experience are encountering in schools, and thereby also contribute to improvement of teacher education in the arts.

In this article, we will present a study that explored arts education practices in two primary schools, one in Sweden and one in Norway, that were known to focus on the arts subjects. The purpose of the study was to examine how education in the arts subjects was carried out in the schools, and how the actors perceived, articulated and legitimated the educational practices in the arts subjects. In the following, we will briefly describe the educational context in the two countries and present the methodology and design of the study, before the main presentation of two cases in detail. Finally, we will discuss possible implications of the case descriptions.

\section{Framing and conducting the study}

Scandinavian countries have to some degree a shared history, language and culture. The educational systems (including primary schools), steering documents and curricula have much in common, therefore, and this also applies to the situation for the arts subjects in schools. Scandinavian educational ideals stress equality, democracy, and a general liberal education for all citizens (Blossing et al, 2014; Telhaug et al. 2006). Scandinavian children start school at around age 6, and primary and lower-secondary education last for 9-10 years. During these years, the arts subjects, including music and arts and crafts, are allotted relatively few contact hours in school, although they are compulsory subjects. Since comparison was not the aim, the researchers chose not to emphasize national affiliation. In fact, some of the variations between the two schools in this study could be the result of different local school politics as well as differences in national education policies.

The study was practice-based and empirically oriented, and not founded on specific, predetermined theoretical assumptions. The research has drawn upon literature and earlier research on arts education, aesthetic experience, children's culture, school development, and curriculum research (Christophersen et al, 2015; Hjort \& Thörnqvist, 2012; Aure, 2011; Dahlbäck, 2011; Fahltin, 2011; Malmström, 2009; Sæbø, 2009; Thorgersen, 2007; Lindgren, 2006; Bresler, 2005; Saar, 2005; Stake, Bresler \& Mabry 1991). As arts experiences, arts learning and arts teaching are not isolated happenings, an ethnographic approach has been used to come close to the actors' perspectives on and experiences with the arts, as well as the interaction between pupils, teachers, and materials. In addition, the researchers have looked beyond the specific situations and also considered contextual elements such as historical conditions and traditions within the arts, as well as constraints, opportunities and limitations within the school contexts and the schools' local communities.

The study was designed as an ethnographic double case study. This allowed for practical variations in the data collection process (Gerring, 2007); while keeping the same object in view, i.e. the description of the schools and the arts education practices, the researchers could go about it differently to adjust to the daily life at each school. In addition, since case study analysis implies in-depth study of a few examples, it allows for the desired theoretical generalization; that is, an extrapolation of relevant and fundamental issues regarding the situation for the arts in schools. The schools were strategically selected based on the following criteria: They should be primary schools (including pupils age 6-13) with a clearly articulated commitment to the arts subjects. Two schools were selected: "Bayview" 
school in Norway (grades 1-7) and "Parkside" school in Sweden (grades F-6). In both schools, the subjects of music and arts and crafts for the 10-11-year-olds ${ }^{3}$ were selected as locus of the study.

The methods selected for data collection were observation, individual interviews with teachers and school leaders, group interviews with pupils and teachers, and informal conversations with teachers, pupils, and school leaders, as well as the schools' local policy and strategy documents ${ }^{4}$. Data was collected during the school year 2013-2014. In addition, artefacts from the arts and crafts lessons were documented. We concentrated on activities in the music and arts and crafts classes, but also included interdisciplinary arts education activities, as well as incidents in everyday school life and communitydirected activities. The observations and informal conversations were documented through field notes, and the interviews were recorded and transcribed. In the first stage, the generated texts were analysed individually by the researchers. Content analysis was used, searching for significant factors that could describe the preconditions for arts education in the two schools (Graneheim \& Lundman, 2004). This first stage of analysis resulted in the writing of the two narrative case descriptions, which were later analysed collaboratively by the two researchers. This analysis helped guide the researchers' final discussion of the implications of the case descriptions, and thereby also to give an answer to one of our initial questions: What could be learned from these schools?

\section{Bayview and Parkside schools: Case descriptions}

In order to examine and understand the arts education practices in the schools, or more specifically how arts education was carried out, perceived, articulated and legitimated, the researchers constructed two narrative case descriptions, based on content analysis of the data material. These descriptions are presented in the following.

\section{Bayview primary school}

Bayview primary school has 280 pupils, and is located in a blue-collar ${ }^{5}$ community outside a relatively large city. The school buildings have recently been renovated and appear bright and modern. It is school policy to use only pupils' works for decoration, and there is consequently a carefully selected exhibit of pupils' visual art works in the building. The arts are involved in many events during the school year: Both $3^{\text {rd }}$ and $7^{\text {th }}$ grades have annual stage productions, and there is an annual community art exhibition displaying work produced by all of the pupils. The school has two choirs, and all grades arrange performances for the parents during the year.

Bayview is an open plan school. All of the pupils are assigned to a base (base 1-4 or base 5-7). Within each base there is an open space that is divided into smaller areas using bookshelves and screens; group rooms, a computer room, a lecture room, and a teachers' workroom are part of the area. Each grade is normally divided into two music groups and three arts and crafts groups. Group divisions in other subjects are decided by the teachers and depend on the subject matter, learning objectives, and pupils' needs. It is essential to limit noise and disturbance in open plan schools, and Bayview has implemented a program to support and promote positive behaviour and social

\footnotetext{
${ }^{3}$ The pupils included in the study were born in 2003. This equals 4th grade in Sweden, 5 th grade in Norway

${ }^{4}$ The retrieval of informed consent and the collection of data were carried out in accordance with Swedish and Norwegian official guidelines for research ethics, and have been recommended by the Norwegian Data Protection Official.

${ }^{5}$ This characterization of the Bayview community is based upon recent survey information about education, income, life expectancy, etc. regarding different areas of the city in question. The survey is commissioned by the municipality and is publically available, still, for anonymity reasons we have chosen to not refer to it here.
} 
competence among the pupils; the principal speaks highly of the program and its effects. The arts teachers are more ambivalent. On the one hand, they consider it a helpful tool to establish silence and concentration, and thus, better learning conditions. On the other hand, they experience a contradiction between this conformity and the need for creativity in the arts. According to Tom, "Behavioural programs reward rule-following and conformity while the arts encourage creativity and thinking outside of the box". Jasper and Tom both voiced a subtle concern that the intended standardization of behaviour may affect the children's creative abilities and their possibility to blossom and enjoy the arts. They also admit to a certain pressure from other teachers to curb the pupils' enthusiasm in order to avoid sending overly excited (and thus loud) pupils through the corridors and back to base.

Because local school authorities prioritize reading, arithmetic and communication, Bayview is obligated to emphasize these skills, but the school also has special education and the so-called "practical ${ }^{6}$ and aesthetic ${ }^{7}$ subjects" as its priority in the local strategic four-year plan. A new local curriculum is under development, and a group of teachers have met regularly to discuss a joint strategy for these subjects. While the current plan refers to the arts as means for achieving other goals, the discussion in the teacher group revealed more nuanced view. Although the teachers recognize the potential benefit of the arts for school life and academic achievement, they stress that the arts are not just "fun" or "useful". Megan, a music and arts and crafts teacher, pointed out that "The arts are not just a respite. You learn something, and it is fun". On the question of why the arts are taught in schools, the teacher group listed several arguments: The arts are about work forms in which materials are shaped into a form, which gives pupils the opportunity for creative expression, mastery, interaction, and shared experiences. Moreover, the arts contribute to personal development, understanding of life, and a sense of community, as well as being a source of joy. The fundamental idea underlying all the other justifications appears to be that the arts contribute to the whole person, and are therefore essential to make the school a good place for all pupils. Julia, the principal, stressed this point:

A person is much more than just reading and doing math. They say that each child should go to bed with a hundred experiences of mastery under the pillow, and this is our concern every day. When I think about the feeling of loss that many children experience every day, it breaks my heart. When our pupils go on to lower secondary school, they should have used all the senses and different sides of themselves. That's really what it is about, isn't it: What does it mean to be a human being?

Pupils with special needs are often entitled to alternative education. Based on the idea of the whole person, Bayview has created alternative learning arenas based on pupils' interests, such as film, photography, music, carpentry, cooking, and outdoor activities. In addition, multi-handicapped and seriously ill pupils at Bayview are offered individual music lessons, sometimes even in their own homes during school hours.

The teachers express a pragmatic attitude towards the situation of the arts in schools. For instance, Tom, the 5th grade music teacher, considers the distinction between the arts as goals or means irrelevant: "If somebody needs to justify music because it supports other subjects, go ahead! I am just happy to see kids enjoying themselves, making a sincere and enthusiastic effort". The perception of the arts as meaningful to the pupils was corroborated in an interview with 5th graders. One pupil, Zoe, says she wants musical activities to be part of her life, and she appreciates arts and crafts for the same reasons: these subjects allow pupils "to be creative and express ourselves through art and music".

\footnotetext{
${ }^{6}$ Physical education and food and health

${ }^{7}$ Music and arts and crafts
} 
According to Wayne, the arts are important because they allow "us to use our bodies". In a school survey, the pupils ranked the arts well above average: arts and crafts were highly regarded by $80 \%$ of the pupils, and $60 \%$ also valued music very positively.

A total of 25 teachers are employed at Bayview; almost all are general teachers. Most have taught arts and crafts or music, and have also been involved in interdisciplinary arts activities, such as performances, exhibitions, etc. Many have some formal competence in one or more of the $\operatorname{arts}^{8}$, and some have a highly specialized competence; for example, Tom is a professional musician with an MA in music education, Jasper is a graphic designer, and Susan is the author of academic publications in the field of arts and crafts. According to the principal, the employment of specialist teachers is a deliberate choice made in relation to education quality: "It has been a common view that everybody can teach everything in the lower grades. That is of course nonsense. I want qualified personnel". Consequently, Julia has personally recruited several of her staff on the basis of their qualifications in the arts. The interviewed 5th graders uninvitedly mentioned their teachers' expertise as very positive.

In arts and crafts, the 40 pupils in 5th grade alternate between textile work, metal/woodwork, and visual arts/design. Depending on the activities, the lessons may be located in the open base, but are often carried out in separate rooms in the basement. In accordance with the local curriculum, the pupils sew, knit, and make ping-pong rackets in the crafts classes, while the visual arts/design classes include activities like croquis, lino print, computer graffiti, and pictograms.

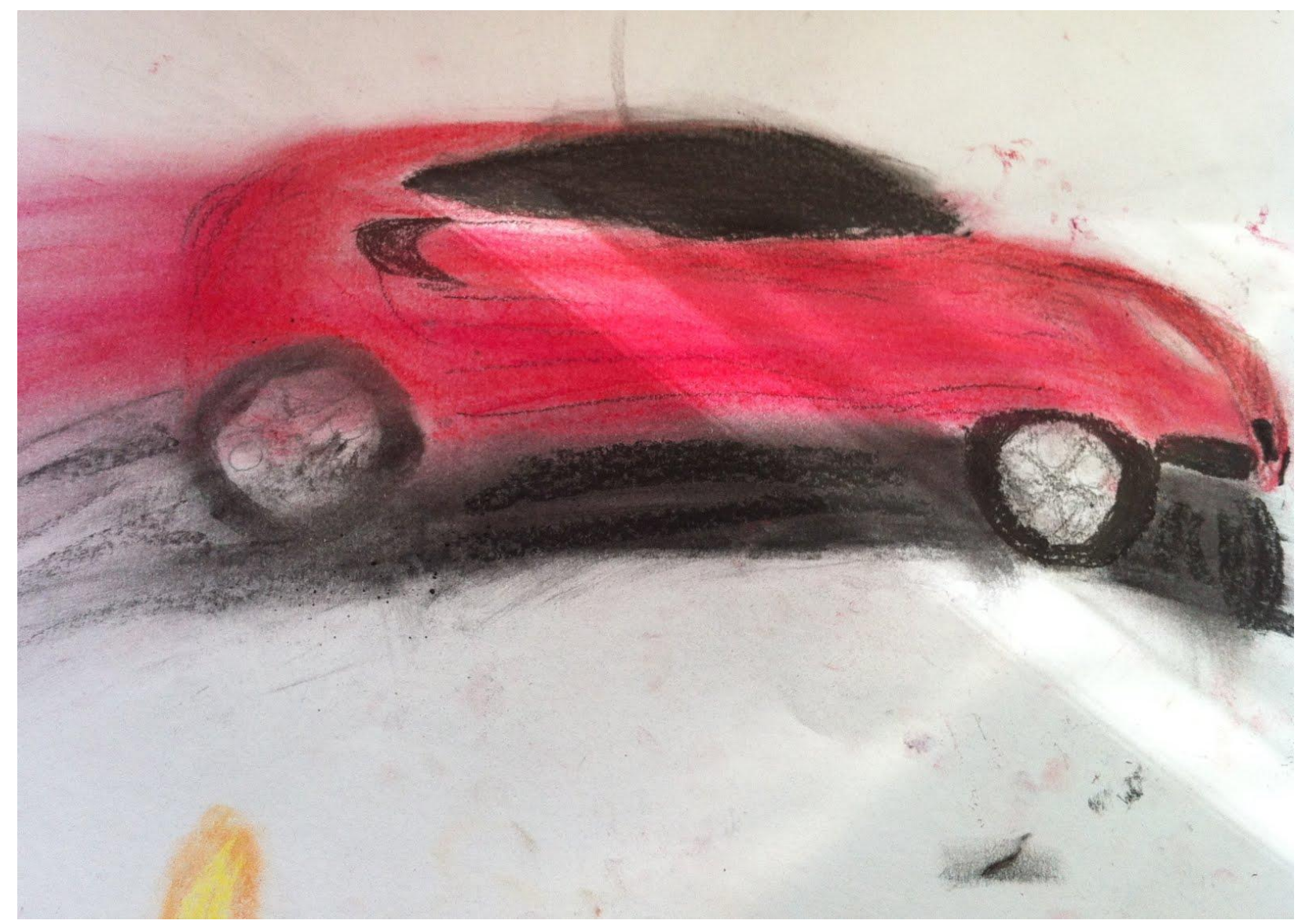

Picture 1 A large format drawing with pencil and chalk, attempting to capture speed

\footnotetext{
${ }^{8}$ Dance, drama, literature, photo/film, music and arts and crafts
} 
Jasper, the visual arts teacher, stressed the importance of fostering the pupils' ability to develop a personal form of expression, self-awareness and assertiveness; of releasing the creative sides of every pupil; and of making the pupils aware of visual elements in society and culture. He was critical of the traditional decorative focus of school art, such as the reproduction of seasonal objects: "If we are to take this seriously, we have to release the creativity". Jasper tries to open up the activities as much as possible while still bearing in mind the age and competence of the pupils: "I give them relative freedom. If they have no limits, they won't know what to do. They need an assignment and a direction". The five pupils interviewed in this study spoke highly of arts and crafts: "I remember when we were supposed to draw somebody who was posing" Vanessa giggled, "Those drawings were funny. I was embarrassed and had to apologize to the people I drew". The pupils expressed a desire to learn more about artists and their paintings, to learn how to sculpt, and to improve their painting skills.

Music classes at Bayview are located in rather small lecture rooms with fixed seating. However, the school is proud that it has a culture hall, which is used for more space-demanding activities like dancing, band practice, concerts, etc. The music teachers cope with the lack of floor space in the lecture rooms by using the space creatively. During the year, the $5^{\text {th }}$ graders at Bayview focused on body percussion, drum playing, and singing; and they rehearsed for and held performances, such as a winter song event to which parents were invited. Notwithstanding his preference for practical acoustic music activities, Tom feels obligated to develop the pupils' digital competence, and has included music technology and multimedia in his teaching.

One April morning, the $5^{\text {th }}$ graders finished recording a music video. They had rehearsed the song throughout the year, and had also spent hours outside during winter shooting film footage. The pupils were now lined up in the music room, all trying their very best to look and sound good. The song was a nostalgic, simple, almost naïve song about winter and childhood memories. Jack, a musician colleague of Tom, and Daniel, a crafts teacher with a special interest in film, had rigged the room with microphones and cameras. The pupils worked hard to produce a series of takes while Jack, Tom, and Daniel supported and guided them. Four takes, two toilet breaks, and one hour later, Jack and Daniel had what they needed for mixing and editing. When asked what they had learned, the pupils answered "to sing in time", "to patience", and "that being in a studio is hard work". To wrap up the session, Jack played the last take of the music for the pupils, who sat completely still and listened reverently to their own voices, almost amazed. One boy, Afran, seemed overwhelmed and tried to hide his face in his hands, but he could not hide his satisfaction and pride.

According to Tom, music has been important in all societies at all times, and is therefore a natural part of general education. "I do not teach musicians", he said, "I teach music", and stressed that music in school should be for all and include collective, but differentiated activities: "Everybody should have the opportunity to learn everything; nobody should be left with nothing". He considered music to be crucial for the pupils' individual development. Incorporating music creates confidence and is highly developmental: "When pupils enter into flow or into a zone, and everybody is in the beat at the same time, you can actually see the learning; you can see the flower unfolding". The interviewed pupils clearly valued music, and looked forward to learning more about singing, dancing, reading music, and performing. They valued intensive and time-consuming music projects, but they considered it unfair that music had to suffer cuts the rest of the year to accommodate these: "We get less music afterwards", Peter said, "so we have to do math in music class, we should rather take time from Norwegian classes, because we have so many of them". His classmate Wayne agreed: "we need music - it is just as important, maybe even more". 


\section{Parkside primary school}

Parkside is an F-6 school, located in a middle-class metropolitan area with around 350 pupils and 23 teachers. The school is rather modern, and each grade has their own space, including two larger classrooms, and a couple of smaller rooms. The music room is located in the grade six area and the craft rooms in the cellar, but there is no art room. Four of the teachers teach art, two teach music, one teaches textile crafts, and one wood and metal work. In the team that is largely responsible for the $4^{\text {th }}$ grade class that was closely followed in this study, the majority of the generalist teachers were very interested in the arts subjects and include them in their daily teaching. One of the music teachers and both crafts teachers have a specialist education in their subjects, but none of the art teachers. There were 52 pupils in grade four, who were grouped in different constellations depending on what subject they were having; most of the time they were divided in two groups of 26 . For the crafts lessons, however, the pupils were in groups with a maximum of 16 . There were about five pupils with special needs in the group, and the ordinary teachers were expected to deal with this and adapt their teaching to the pupils' needs.

In addition to the mandatory arts and crafts lessons, the pupils have a slot in their timetable where they can choose what activity they want to participate in: "the pupil's choice". For example, they have been offered drama, music, theatre masks, ball sports, film-making, and woodwork. At the time of the study, however, the principal decided that half of this time should be made available for "theoretical" subjects, which upset the pupils and the arts teachers. The principal, Cathy, wanted to offer the pupils the opportunity to gain a deeper understanding in their own areas of interest, by being creative and using alternative forms of expression in meaning making.

In addition to that, the school offers optional activities such as choirs and rock bands, as well as after-school activities like painting at snow, making art with leaves, knitting, sewing, and constructing $3 \mathrm{~d}$ art. Additionally, Cathy is continually applying for money to hire artists to come to the school and work with the children. For example, the pupils have been involved in dance activities and creative writing. They also have the opportunity to perform and to display their arts and crafts projects for other pupils, as well as in open performances for parents and relatives.

The arts subjects have a high status at the school, equal with all the other subjects, although some pupils have said that they do not really understand why they should learn music and art in school. However, it seems as if art has been undervalued for some years. The well-equipped art classroom was taken away to make room for a music classroom. The art classes, at the time of the study, were located in the ordinary classroom, which made it difficult to use a variety of materials and to fully utilize the time. It was almost impossible to work with clay as well as other 3D-material and constructions, and both Amy, the art teacher, and not at least the pupils were missing this.

Both Cathy and the teachers stated that the highest status arts subject is given to music.

Well, I think that music has the highest status. I think so. But that is mostly due to the fact that there are two teachers. And that it is possible to get a lot of music education at this school (Brenda).

The music room is well equipped, with guitars, keyboards, digital drums, bass, PA, a lot of percussion instruments and computers with keyboards. Sometimes the two music teachers, Brenda and Claus, teach together, and have the opportunity to divide the group into smaller units. Even the craft rooms are well equipped with tools and machines. The rooms are, for practical reasons, located in the cellar. The pupils really enjoy this subject; some come early to class and want to stay after it has ended. 
When they were asked about memorable events, the pupils primarily mentioned events from the crafts lessons.

Yes, I have a memory. The first time, or the first time I had textile crafts, when I sewed my doll for the first time. My first doll. It was cool. I felt kind of, I can sew (Sarah).

The pupils have 50 minutes of music per week. The music teacher is motivated by the idea that the pupils should feel that music is something for them, that they can sing and make music. In the fourth grade, Swedish folk music and composition are in focus. The pupils say that music is different from other subjects and somehow more free. They enjoy singing and learning a bit about Swedish music history, but they also want to learn more about modern music and how it functions, and to create digital music.

No, it can't just be useful, but it can be fun to know how they did it kind of. How they made old instruments, because I thought it was a bit strange that they made bag-pipes of cow stomachs (Fred).

The pupils also have 50 minutes per week for art education. The most important motivation for the art teacher, Dorit, is that the pupils gain self-confidence, and dare to share their works. She also values the more existential dimensions of the subject.

When you work with art you open your perspective. You become aware of what things look like. You kind of study (Dorit).

During the observation period, it became obvious that the art teacher worked a lot with clear instructions, which functioned as frames for expressive freedom, and she also valued concept acquisition. The pupils were expected to construct a personal paper convolute for two-dimensional artworks. Another task involved folding a paper in half and drawing a form on the one side, then copying it and finally colouring the one half inside the form, and the other half outside the form, in order to gain an understanding of symmetry.

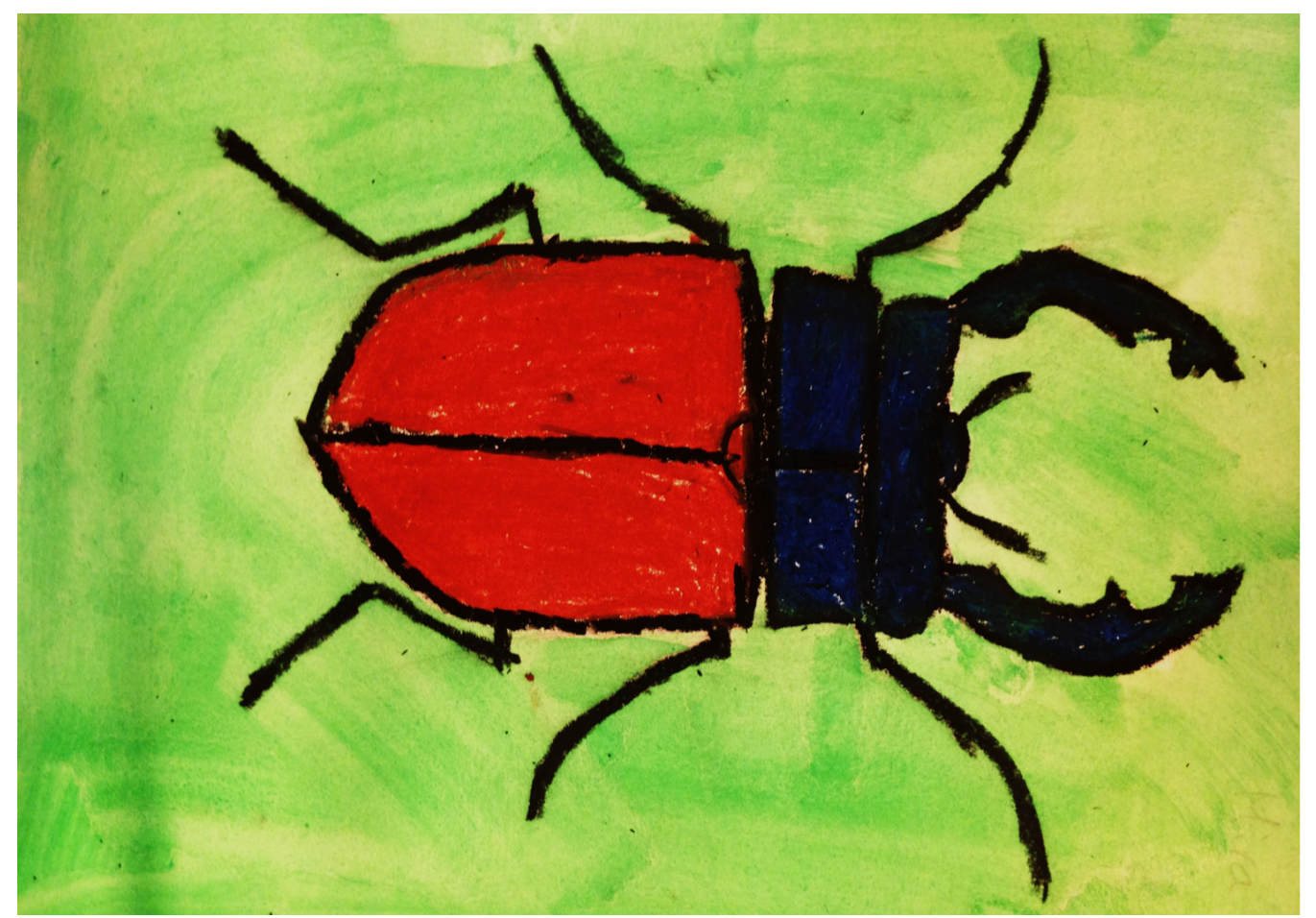

Picture 2 Pastel crayon motive on watercolour background 
The pupils were to use pastel crayons for the picture, and later used water colours for the background (see picture 2). A third task was to draw an animal, which they associated with a Swedish region that they were working with in other lessons. Finally, they were to draw an autumn picture and colour it with watercolours. The interviewed pupils said that art is a subject that is more relevant than music for school, since an understanding of pictures is important in social life; moreover, they like to draw. They miss working with other materials in addition to paper and pens and watercolours though.

What we did in grades one, two and three. It was like half-half. Some days we were drawing, and some days we made 3D-stuff (Martha).

With regard to crafts, which have 80 minutes per week, Dorit values the fact that the pupils become familiar with different materials, and that they learn various techniques and how to use the different machines. She also stresses that crafts can be necessary to cope with social life in the future.

I point that out all the time; this is a school subject. I have instructions, and my goal is that they should learn to handle the tools and techniques that exist here (Dorit).

The teacher stresses that she considers it much more important that the things the pupils make are functional, than they are concerned with the details and finish. At the time for the investigation, the pupils were making and appliqueing chair cushions, sewing covers for iPhones or iPads, and building a wooden case or a small cabinet. To produce these artefacts, the pupils had to draw a pattern or a layout, to cut or saw, and to use a sewing machine, a saw, a drill, a cordless screwdriver, and/or a hammer. In crafts class, the pupils were also expected to document and reflect upon their work progress.

The pupils appreciated this subject a great deal, and enjoyed making things in a calm atmosphere. As one pupil put it:

It's like, when you can create things yourself, it is really fun. And you can also take home the things that you make. You really feel that "I have made this myself" (Peter).

The pupils said that they felt that their crafting was rather too controlled. They had to follow strict instructions, and in the woodwork lessons, the teacher took over some of the operations himself.

On the whole, Cathy, the principal, values the arts subjects and arts activities, and wants them to saturate the daily work of the school, as well as the learning processes of the pupils. She wants the pupils to develop insights and incorporate this knowledge in various subjects by working with different art forms. However, she considers that the impetus for maintaining and developing highquality arts work must come from the teachers themselves. She is willing to support, if the teachers share realistic and well-motivated ideas with her.

If they say: "Principal, we want to do this". Yes, we fix it. But it has to come from them. I can't say this is what we can do, come on, because I can't sit and do it in here by myself. They must be willing to do it. Then there are no hindrances (Cathy).

For example, Brenda, the music teacher, at the time for the interview, suggested that the grade four should sing for 20 minutes each morning for a period, and all involved teachers were willing to try. The principal also created a school development team that has the responsibility and power to influence the activities. Thus, it seems that the teachers are involved and engaged, and well supported in the running of the school, even with regard to determining the role and function of the arts subjects. When new teachers are employed, engagement in the subject and interest in supporting pupils and their learning, were more highly valued than subject-specific qualifications. Another feature that influences the atmosphere in the school is the stress placed on the importance of all pupils being involved and engaged, and feeling that their ideas count. It is considered more important for the pupils 
to participate and be parts of the experience, to develop self-confidence and understanding and be able to cope, than it is for them to acquire technical skills or good grades or degrees.

\section{The arts in Bayview and Parkside schools: some implications}

In a time where the arts in schools are perceived to be not only under pressure but also losing ground allegedly due to low teacher competence, lack of prioritizing by school authorities, and neo-liberal views regarding quality in schools - the Bayview and Parkside schools are actually stressing and focussing on the arts, as show in the case descriptions. In the following, we would like to reflect on some implications of the case descriptions under the over-arching question of what could be learned from studying the place and perception of arts in these schools? More specifically, we will focus on four themes that emerge from the case descriptions: Arts education in every-day life in school, educational leadership, educational philosophy, and issues related to frames and freedom.

\section{Arts education as part of daily life in schools}

Inspired by the Minecraft ${ }^{9}$ computer game, pupils cut, painted and constructed figures with wooden cubes as part of a mathematics project; they sang songs about friendship and community; and they were offered opportunities to participate in arts activities as part of the schools' special education initiatives. Highly skilled teachers also trained the pupils in arts-specific techniques and concepts, and the pupils participated regularly in arts activities inside and outside of the school buildings; for example, not only as an audience for performances, but also on stage as dancers, actors and musicians, as well as artists whose works were preserved and exhibited.

The arts may be perceived in various ways in schools: as a means to learn other subjects, or as a means to learn specific skills or attitudes; the latter could be termed education through art, or art as education In addition, the arts may be considered valuable in themselves, in which case both the learning of the art forms and pupils' own artistic experiences would be important; this could be termed education in the arts and education as art (Bamford, 2006). As shown above, all of these perspectives are to be found at both Bayview and Parkside. By all indicators, therefore, these schools are so-called arts-rich environments (ibid.).

Some studies have highlighted the challenges associated with the perception of the arts in schools as decorative (Saar, 2005; Stake et al, 1991) or as extraordinary events (Borgen \& Brandt, 2006). As our data shows, this is clearly not the case at Bayview and Parkside. At these schools, the arts are visible and audible features of everyday life, and sorely missed by the pupils when classes for some reasons are cancelled or when the teaching hours are transferred from the arts to other subjects or projects. Educational and aesthetic philosopher John Dewey (1934) criticized the idea that the arts can be separated from the normal processes of living. A key point in Dewey's critique of art for art's sake is that the elevation of art into something extraordinary that must be experienced in particular arenas, separates the arts from daily life, thereby diminishing art's opportunities for enriching human life. It may seem that Bayview and Parkside schools have practically fulfilled the task that John Dewey called upon aesthetic philosophy to address so long ago, that of restoring the continuity between the arts and daily life.

\footnotetext{
${ }^{9}$ Minecraft is an online computer game that is built around resource gathering and Lego-like creative construction of buildings, structures and landscapes.
} 


\section{Educational leadership}

As shown in the case descriptions above, the schools' programs and activities comply with the criteria that other studies have identified as success factors for the arts in schools. These include flexible school structures; inclusive approaches for engaging the pupils; a high degree of collaboration between teachers, between schools and artists, and between school and community (Bamford, 2006); learning in and through the arts (Burton et al, 1999); and educational leadership (Sæbø, 2009; Stake et al, 1991).

In an early study of the arts in schools, Stake, Bresler and Mabry (1991) noted that their research design changed as soon as they realized that the quality of the arts in schools was closely linked to leadership: "Where we found the arts thriving, we found instructional leadership at some level committed to arts education" (p. 321). Several more recent studies have also stressed how crucial the educational leadership is for arts education (Bamford, 2012; Swedish School Inspectorate, 2012; Sæbø, 2009). Our data supports this finding: The educational visions of the Bayview and Parkside principals include the arts. They have expressed a strong conviction that children need access to various types of experiences, that the arts have a natural place in general education and that the arts require skilled teachers, and this conviction is reflected in the value placed on the arts, which equals or even exceeds that placed on other school subjects.

In order to prioritize the arts in their schools, the principals have had to be creative, given their relatively limited budgets and the constraints placed on them from local and national school authorities. This has been possible due to the high degree of autonomy they have with regard to timetabling, staff recruitment and programme organisation (Bamford, 2012, p. 23). Pragmatically, this means that, as long as the schools' maintain a satisfactory level of goal attainment regarding the basic skills in the core subjects, the principals can do more or less what they want. Thus, in theory, all schools could prioritize the arts. But this has not happened, and one possible explanation could be that schools' commitment to the arts is somehow connected to the principal's interest and dedication. This is corroborated by school improvement research that has revealed a close link between a school's development and the principal's competence, drive and interests (Fullan, 2014; 2007; Swedish School Inspectorate, 2012; Hargreaves and Shirley, 2009). Research further suggests that leadership and school outcomes are closely related, and that principals in successful schools are heavily engaged in the school's core activities (Törnsén, 2009).

The principals in our study were not reclusive administrators; they were visible in the schools' daily activities, and they emphasised the importance of good communication and relations between principal, staff and pupils. This is a not just a strategy to increase satisfaction in the workplace, but also an effective means of creating a sense of direction. Our data suggest that there is a shared discourse about the arts in each school, in which the principals, the teachers, and the pupils all talk about the arts in a similar way. Such a shared understanding is usually interpreted as being an outcome of an effective school improvement process, which is, in turn, a pre-requisite for the successful implementation of programmes and initiatives (Hopfenbeck et al, 2013; Leithwood, Harris and Strauss, 2010). In other words: educational leadership has a great impact on school priorities and activities. Consequently, the principals may be perceived as the grey eminences of arts education in schools; highly influential, but not very visible. This indicates that contextual issues like organization and leadership are crucial for arts education in schools, and that discourses on arts education should not be limited to the emotions and experiences cultivated in the pupils' encounters with the arts, or to the pedagogical relationship between teacher, pupil and content. 


\section{Holistic and inclusive approaches to education}

One of our research questions targets the perceptions of and justifications for the arts, in order to provide insight into the educational philosophies surrounding the arts in the two schools. Based on the case descriptions, two features are noteworthy: the schools' holistic approach to education, and their stance on inclusion.

Both schools have taken a holistic approach to education, in which the arts are perceived to involve and contribute to learning in the broadest sense, as well as to social and personal growth. The arts are not inferior to other subjects in these two schools; they are equally valued because they are considered to contribute to the well-rounded development of the whole human being. Arts education is considered to serve a variety of purposes; while it is sometimes utilized to achieve other goals than the artistic, it is the intrinsic value of the arts that is emphasised. Arts activities are perceived as important for pupils' self-awareness, self-expression, communication, and coping in the world, both practically and existentially, and these are values that are highlighted in the curricula as well (Leijonhufvud \& Ferm Thorgersen, 2015).

These perceptions of the arts are slightly different from those expressed in Lindgren's (2006) study of teachers' and principals' views of the concept of aesthetics. Her study identified and described various discourses concerning the construction of the legitimacy of aesthetic activities in schools; these include compensation, balance, joyful activity, nurturing and reinforcement. Lindgren's results showed that two dominant discourses, education for freedom and exercising social control in the name of aesthetics, guided the approaches and statements of the interviewees. These perceptions of the arts are also present in our study. Nevertheless, the holistic approach expressed in the Bayview and Parkside schools, encompasses more than the slightly instrumental perceptions expressed by Lindgren's informants. The existential, communicative, Bildung-oriented and artistic perspectives evident among our informants are more in accordance with Bamford's (2006) aforementioned findings regarding the relations between education and the arts; Education in the arts, Education through the arts, Arts as education and Education as arts.

Ideas related to special education are integrated into the education philosophies in both schools, which also influences how arts education is performed and how arts activities are offered and motivated. The schools' holistic approach to arts education clearly implies an idea of inclusion: the arts are for all pupils. The concept of inclusion in schools is related to the concepts of integration and participation (Stier, 2014), and it is evident that these concepts impact arts education in several ways: Both schools recognize that pupils communicate in different ways, and that the traditions of verbal expression associated with formal education do not suit all pupils. It is therefore considered essential in both schools to allow for various media of expression. Furthermore, all of the pupils are expected to participate and be involved, which may be challenging for the teachers (Ferm Thorgersen, 2014; Tøssebro, 2004). Group size, for instance, is not necessarily adjusted, even when pupils with special needs are present. The concepts of integration and participation can thus be contradictory: Individual involvement in aesthetic learning processes - characterized by access, ownership, and belonging - may require small groups of pupils, explicit content and goals in the syllabuses for the current grade, and individual facilitation (Ferm Thorgersen, 2014; Haug, 2014). Finally, the schools organize special arts activities for pupils with special needs, which imply an almost therapeutic view of arts education (Varkøy, 2001, Nielsen, 1998). 


\section{Frames vs. freedom}

The tension between frames and freedom showed to influence the function and role of arts education and activities at the two schools on three levels. Firstly, it is evident at the organizational level where the conditions for the school subjects are decided. What it is possible to achieve among (arts) teachers at a specific school is regulated by the leadership, the organisational structure and the school culture (Mullen \& Schunk, 2010). This influences what may be possible in arts education with regard to personnel competence, budgets, the employees' impetus, support from the principal and colleagues, and expectations of pupils and parents, as well as the schools' explicit education philosophy. The tension at this level can be defined as frames vs. freedom for a professional community (ibid.). Hence, it should be important to encourage an ongoing discussion among teachers regarding these frames, with the aim of developing professional communities with a specific focus on arts education.

The second level, the vocational level, is related to the conditions that govern the teachers' professional and discretionary actions. This field of tension is constituted by the actual frames at the school vs. the freedom for the teachers to develop creative milieus, activities and learning (Posner, 2004). Locations, group sizes, schedules and equipment influence teachers' actions and establish frames for what is realizable within and between the arts subjects at Bayview and Parkside. Poetter (2014) states that teachers' joint consideration of how the frame factors' impact on teaching and curriculum can affect the classroom and school setting positively. The freedom of teachers, their discretionary power (Houmann, 2010) is shaped in the interplay between knowledge, action and motivation. Houmann further states that the creation of discretionary power develops when what she defines as the inner reality of a music teacher (for example knowledge, needs, and values) corresponds to the shape and nature of external reality (the actual frames). In relationships with pupils and colleagues, different balances of power, control, demand, social support and trust can be identified (ibid.) The teacher's discretionary power is exercised in the relationships between music teachers and their institutional settings, music teachers and their tasks, and music teachers and others. Houmann's concepts have been developed in a music education setting, but could be employed to shed light on the tension between frames and teacher's freedom in arts education generally.

Thirdly, the classroom level sets the frames for pupil's arts learning. The teachers' own ideals, the goals and content description of the syllabus, and the instructions given, as well as how the available instruments and tools are to be handled, define the limitations as to how creative the children can be in their arts learning processes. According to the teachers in our study, it is sometimes difficult to allow for the pupils' expressions and creativity. This corresponds with Schwartz' (2006) claim that it is often considered easier and preferable to teach techniques rather than creativity in arts subjects. Frames may be considered prerequisites for creativity (Sawyer, 2010; Strandberg, 2007;), which is a view expressed by the teachers. However, frames can also hinder creative expressions and learning among pupils if they are too narrow. According to Sawyer (2010), creative processes may be characterized by the following features: putting process before product and problem finding before problem solving, perceiving arts as languages, valuing the collaborative process, and reflecting upon ready-made clichés in the arts. Further investigation is required to explore how such processes can be realized in arts education.

\section{The arts: special or equal?}

In this article, we have described and discussed arts education practices in our two cases: one primary school in Sweden and one in Norway that are both considered to focus on the arts subjects. The arts 
subjects have equal status as other subjects in these schools, pupils are expected to come to arts education and to work equally hard as in other subjects, pupils are offered special education in the arts as in other subjects. Also, the principals made an effort to hire competent arts teachers, and to ensure that the arts have reasonable practical and financial conditions. We found that the arts are parts of a holistic and inclusive educational vision in these schools that extends beyond the arts subjects. This vision encompasses a holistic approach to everyday life in school and to the pupils' development and growth. From such perspective, the means-goal nexus that is so commonly employed in debates about the arts appears to be somewhat artificial. That is so, because, as shown in the case descriptions showed, the arts in ordinary school life will inevitably be both. In addition, the case descriptions imply a tension between frames and freedom that characterizes the arts at several levels.

We were initially under the impression that Bayview and Parkside schools could be perceived as special because they prioritize the arts. During this research project, we have had to revise our perceptions: The schools are special, not because they prioritize the arts, but because the arts are not treated any differently from other subjects in the curriculum. Music and arts and crafts do not have to fight for their existence in these schools. Because of this they appear unique - just like other subjects do. Or as one of the principals said: "I think the arts are as prominent as any subject".

\section{On the contributors}

Dr. Catharina Christophersen is Associate professor of Music Education at Center for Arts, Culture and Communication at Bergen University College, Norway. Christophersen is a general teacher as well as an experienced music teacher and educator. She holds a $\mathrm{PhD}$ from the Norwegian Academy of Music, and has published internationally in music education and arts education. Her research is critical and empirical, and concerns popular music, higher music education, and arts in schools.

Dr. Cecilia Ferm Thorgersen is Full Professor of Music Education at the Department of Arts, Communication and Education at Luleå University of Technology, Sweden. She holds a PhD from LTU, and has published internationally in music education and education. Her research is both philosophical and practice based and concerns democracy, inclusion, assessment and equality in varied music educational settings. She is chair of the Nordic network of music education, and program chair for the International Society for Philosophy of music education.

\section{References}

Aure, V. (2011). Kampen om blikket. En longitudinell studie der formidling av kunst til barn og unge danner utgangspunktet for kunstdidaktiske diskursanalyser. [Struggles Over the Gaze: A Longitudinal Study in Which the Dissemination of Art to Children and Young People Forms a Starting Point for Art Didactic Discourse Analysis]. Diss. Stockholm: Institutionen för didaktik och pedagogisk arbete, Stockholms universitet.

Bamford, A. (2006). The Wow Factor: Global research compendium on the impact of the arts in education. Berlin: Waxmann Münster.

Bamford, A. (2010). In her own words: Anne Bamford on Making Arts Education Meaningful. Unesco of Today. German Commision for Unesco. 82-83.

Bamford, A. (2012). Arts and Cultural Education in Norway 2010/2011. Bodø: Nasjonalt senter for kunst og kultur i opplæringen.

Blossing, U., Imsen, G. \& Moos, L. (2014). The Nordic Education Model: 'A School for All' Encounters Neo-Liberal Policy. Dordrecht: Springer.

Bresler, L. (2005). What musicianship can teach educational research. Music Education Research, 7(2) 169-183. 
Burton, J., Horowitz, R., \& Abeles, H. (1999). Learning in and through the Arts: Curriculum Implications. In E. B. Fiske, Champions of Change: The Impact of the Arts on Learning. Washington: Arts Education Partnership. 35-46

Christophersen, C., Breivik, J.-K., Homme, A. D., \& Rykkja, L.H. (2015). The Cultural Rucksack. A National Programme for Arts and Culture in Norwegian Schools. Bergen: Fagbokforlaget.

Dahlbäck, K. (2011). Musik och språk i samverkan - en aktionsforskningsstudie i åk 1. [Music and Language in cooperation - an action research study]. Lic. Göteborg: Göteborgs Universitet.

Dewey, J. (1934). Art as experience. New York: Perigee Books.

Erickson, K. (2005). The Arts: Keystones to learning. Chicago: Creative Directions.

Fahltin, A. (2011). Musik som nav i skolredovisningar. [Music as nexus in school presentations]. Lic. Stockholm: KMH-Förlaget.

Ferm Thorgersen, C. (2014). Estetisk kommunikation för inkludering och delaktighet [Aesthetic communication for inclusion and involvement]. In M. Sandström, J. Stier \& L. Nilsson (eds) Inkludering: möjligheter och utmaningar [Inclusion: possibilities and challenges]. Lund: Studentlitteratur, 172-194.

Fullan, M. (2007). Leading in a culture of change. San Francisco: Jossey Bass.

Fullan, M. (2014). The principal: Three keys to maximizing impact. San Francisco: Jossey Bass.

Gerring, J. (2007). Case Study Research: Principles and Practices. Cambridge: Cambridge University Press.

Graneheim, UH, \& Lundman, B. (2004) Qualitative content analysis in nursing research: concepts, procedures and measures to achieve trustworthiness, Nurse Education Today, 24(2), 105-112.

Hargreaves, A. \& Shirley, D. (2009). The fourth way. Thousand Oaks: Corwin.

Hastrup, Kirsten (1998). Kulturel forståelse : mellem sprog og erfaring [Cultural understanding: between language and experience]. In B. Hodne (ed.) Kulturstudier [Cultural studies]. Oslo : Norges Forskningsråd. 47-65.

Haug, P. (2014). Inkludering [Inclusion]. Oslo: Gyldendal Forlag.

Hjort, M. \& Thörnqvist, E-M. (2012). Konstens betydelse. Om konstarter och litteratur i skola och samhälle [The meaning of art. About arts and literature in school and society]. Nordisk kulturpolitisk tidskrift, 15(02), 287-293.

Hopfenbeck, T. Tolo, A., Florez, T. \& El Masri, Y. (2013). Balancing Trust and accountability: The Assessment for Learning Programme in Norway. A Governing Complex Education Systems Case Study. OECD Education Working Paper. Centre for Educational Research and Innovation, OECD. http://www.oecd-

ilibrary.org/docserver/download/5k3txnpqlsnn.pdf?expires=1409991337\&id=id\&accname=guest \&checksum $=5717$ E86E906E83E00EFEAFBBDBA1C265 [Downloaded September $6^{\text {th }} 2014$ ]

Houmann, A. (2010). Musiklärares handlingsutrymme - möjligheter och begränsningar [Music teachers' discretionary power - possibilities and limitations]. Diss. Lund: Lunds Universitet Musikhögskolan i Malmö.

Leijonhufvud, S. \& Ferm Thorgersen, C. (2015). Music as Art - Art as Being - Being as Music: A philosophical investigation of how Music Education can embrace the Work of Art based on Heidegger's thinking. In. F. Pio \& Ø. Varkøy (eds.) Philosophy of Music Education Challenged. Heideggerian Inspirations: Music, Education and Development. Dordrecht: Springer, 113-128.

Leithwood, K., Harris, A \& Strauss, T. (2010). Leading School Turnaround: How Successful Leaders Transform Low-performing Schools. San Fransisco: Jossey-Bass.

Lindgren, M. (2006). Att skapa ordning för det estetiska i skolan. Diskursiva positioneringar i samtal med lärare och skolledare [Bringing order to aesthetics in school. Discursive positioning in discussions with teachers and head teachers]. Diss. Göteborg : Göteborgs universitet.

Lund, A., Krantz, J. \& Gustafsson, A. B. (2013). Skapande skola: En kalejdoskopisk reform och dess praktik [Creative Schools: A caleidoscopic reform and its practices]. Växjö: Myndigheten for kulturanalys/Linneuniversitetet. http://www.kulturanalys.se/wpcontent/uploads/2013/12/Skapande-skola-En-kalejdoskopisk-reform-och-dess-praktik.pdf [Downloaded 03.27.14]

Malmström, E. (2009). Bilden som resurs i meningsskapande: estetiska ämnen i statliga styrdokument [The Picture as resource in meaning making: aesthetic subject in national steering documents]. 
Paper presented at The Third National Curriculum Theory Research Conference, 15-16 October 2009.

Mullen, C. A. \& Schunk, D. H. (2010). A view of professional learning communities through three frames: Leadership, organization, and culture. Mc Gill Journal of Education, 45(2), 105-204.

Nielsen, F. V. (1998). Almen Musikdidaktik [General Music Didactics]. Copenhagen: Akademisk forlag.

Poetter, T. S. (2014). Teachers Critique the Curriculum: Frame Factors at Play, Kappa Delta Pi Record, 42(2), 82-87.

Posner, G.J. (2004). Analyzing the Curriculum: Frame Factors (3rd ed.). Boston: Mc Graw Hill.

Saar, T. (2005). Konstens metoder och skolans träningslogik. [The Methods of Art and the training logic in school]. Karlstad: Karlstad University Studies.

Sawyer, K. (2010). Improvisation and the Creative Process: Dewey, Collingwood, and the Aesthetic of Spontaneity, The Journal of Aestethic Art Critics, 58(2), 149-161.

Schwartz, S. H. (2006). Basic Human Values: An Overview. Jerusalem: The Hebrew University of Jerusalem.

Stake, R., Bresler, L. \& Mabry, L. (1991). Custom \& Cherishing: the Arts in Elementary Schools. Urbana: University of Illinois Urbana-Champaign.

Stier, J. (2014). Avslutande discussion [Final discussion] In M. Sandström, J. Stier, J. \& L. Nilsson, (eds.). Inkludering: möjligheter och utmaningar [Inclusion: possibilities and challenges]. Lund: Studentlitteratur, 259-268.

Strandberg, T. (2007). Varde ljud!: Om skapande i skolans musikundervisning efter 1945. [Be sound! Creativity in the subject music after 1945]. Diss. Umeå: Umeå Universitet.

Swedish School Inspectorate (2012). Musik i grundskolan. Är du med på noterna rektorn? [Music in Swedish compulsory schools]. Stockholm: Swedish School Inspectorate.

Sæbø, A. B. (2009). Muligheter og utfordringer for kunstfagene i oppleeringen [Possibilities and challenges for the arts in education]. Bodø: Senter for kunst og kultur i opplæringen. http://www.kunstkultursenteret.no/sites/k/kunstkultursenteret.no/files/e3b439d027029b6c3485800 d1651d76f.pdf [Downloaded 02.25.14].

Telhaug, A.O., Mediås, A. \& Aasen, P. (2006). The Nordic Model in Education: Education as part of the political system in the last 50 years, Scandinavian Journal of Educational Research, 50(3), 245-283.

Thorgersen, K. (2007). Unspoken Truths. About Aesthetics in Swedish schools. Lic. Luleå: Luleå Tekniska Universitet.

Törnsén, M. (2009). Successful Principal Leadership: Prerequisites, Processes and Outcomes. Umeå: Pedagogiska Institutionen, Umeå universitet.

Tøssebro, J.(2004). Integrering och inkludering. [Inclusion and integration]. Lund: Studentlitteratur.

Varkøy, Ø. (2001). Musikk for alt (og alle): Om musikksyn i norsk grunnskole. Diss. Oslo: Norges Musikkhøgskole.

Winner, E., Goldstein, T. R., \& Vincent-Lacrin, S. (2013). Art for Art's Sake? The Impact of Arts Education. Paris: OECD Publishing. 